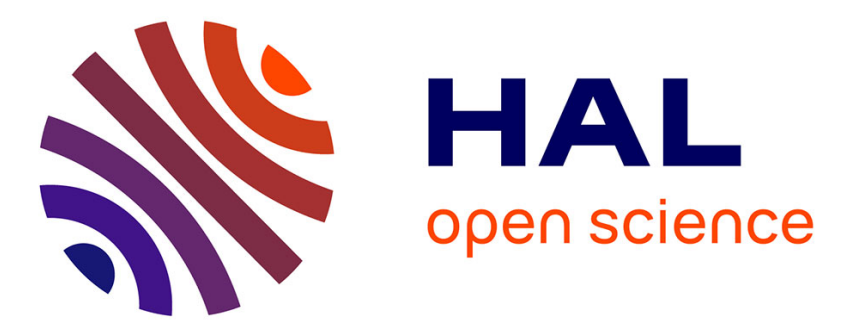

\title{
Large Body Size as a Socially Valued Factor Determining Excess Weight and Obesity in the Context of the Nutritional Transition in Senegal
}

Emmanuel Cohen, A Ndao, B Faye, S Ndiaye, E H M Ndiaye, G Ezan, L Gueye, G Boëtsch, P Pasquet, N Chapuis-Lucciani

\section{To cite this version:}

Emmanuel Cohen, A Ndao, B Faye, S Ndiaye, E H M Ndiaye, et al.. Large Body Size as a Socially Valued Factor Determining Excess Weight and Obesity in the Context of the Nutritional Transition in Senegal. Bulletins et Mémoires de la Société d'anthropologie de Paris, 2018, 10.1007/s13219-0170198-5 . hal-03456121

\author{
HAL Id: hal-03456121 \\ https://hal.science/hal-03456121
}

Submitted on 29 Nov 2021

HAL is a multi-disciplinary open access archive for the deposit and dissemination of scientific research documents, whether they are published or not. The documents may come from teaching and research institutions in France or abroad, or from public or private research centers.
L'archive ouverte pluridisciplinaire HAL, est destinée au dépôt et à la diffusion de documents scientifiques de niveau recherche, publiés ou non, émanant des établissements d'enseignement et de recherche français ou étrangers, des laboratoires publics ou privés. 


\title{
Large Body Size as a Socially Valued Factor Determining Excess Weight and Obesity in the Context of the Nutritional Transition in Senegal
}

\author{
La valorisation sociale de l'embonpoint comme déterminant du surpoids et de l'obésité \\ dans un contexte de transition nutritionnelle au Sénégal
}

\author{
E. Cohen - A. Ndao \\ N. Chapuis-Lucciani \\ Received: 18 April 2017; Accepted: 06 November 2017 \\ (C) Société d'Anthropologie de Paris et Lavoisier SAS 2017
}

\begin{abstract}
Like most African countries, Senegal is experiencing a nutritional transition. Global drivers of sedentary behavior and high-calorie dietary intake, together with local anthropological drivers of large body size as a socially valued characteristic could be exposing the population to obesity. This study therefore set out to assess the impact of this sociocultural factor on the nutritional status of Senegalese adults. We set up 14 focus groups ( $n=84$ participants) and a cross-sectional quantitative survey ( $n=313$ women; $n=284$ men) of adults in three different socio-ecological areas in Senegal (rural: $n=204$; suburban: $n=206$; urban: $n=187$ ). We also assessed perceptions of
\end{abstract}

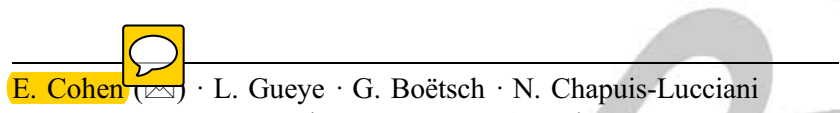

CNRS, UMI 3189 « environnement, santé, sociétés »,

faculté de médecine, UCAD, BP 5005, Dakar-Fann, Sénégal

e-mail : emmanuel.cohen@mnhn.fr

\section{A. Ndao}

CNRS, UMR 8177, IIAC-LAIOS,

École des hautes études en sciences sociales (EHESS),

190-198, avenue de France, F-75244 Paris cedex 13, France

Raum IG 551, Norbert-Wollheim-Platz 1,

university of Frankfurt am Main,

institute of ethnology, DE-60629 Frankfurt/Main, Germany

B. Faye $\cdot$ S. Ndiaye

Département de sociologie, faculté de lettre, UCAD,

BP 5005, Dakar-Fann, Sénégal

E.H.M. Ndiaye - G. Ezan

Laboratoire de physiologie et d'exploration fonctionnelle,

faculté de médecine, UCAD, BP 5005, Dakar-Fann, Sénégal

P. Pasquet

CNRS, UMR-MNHN 7206 « Éco-anthropologie

et ethnobiologie », muséum national d'histoire naturelle,

musée de l'homme, 17, place du Trocadéro,

F-75116 Paris, France body weight (Body Size Scale) and weight status (anthropometric measures). Middle-aged and older Senegalese people value excess weight more than younger Senegalese in all the areas studied. Being female, older, living in urban/suburban areas and valuing excess weight/obesity were independently associated with being overweight/ obese. A higher socio-economic status was also associated with being overweight/obese. A nutritional transition is under way in Senegal in urban/suburban areas, particularly affecting older urban women, with specific cultural factors contributing to this phenomenon. This suggests a need for local measures targeting women and is accounted for by specific anthropological characteristics in the Senegalese population.

Keywords Senegal - Excess weight $\cdot$ Obesity $\cdot$ Body image $\cdot$ Determining factors

Résumé Le Sénégal fait face à la transition nutritionnelle car des facteurs globaux tels que la sédentarité et l'alimentation calorique, et des facteurs locaux d'ordre anthropologique comme la valorisation sociale de l'embonpoint, peuvent exposer la population à l'obésité. L'objectif de cette étude est d'évaluer l'impact de ce facteur socioculturel sur le statut nutritionnel des adultes sénégalais. Nous avons mené 14 focus-groups ( $n=84$ participants) et une étude quantitative transversale ( $n=313$ femmes ; $n=284$ hommes) auprès d'adultes vivant dans trois milieux socio-écologiques au Sénégal (rural : $n=204$; périurbain : $n=206$; urbain : $n=187$ ). Nous avons aussi mesuré les perceptions du volume corporel (Body Size Scale) et évalué la catégorie staturopondérale des individus. Les femmes d'âge mûr et âgées sénégalaises valorisaient davantage le surpoids que les jeunes sénégalais dans les trois zones investiguées. De plus, être femme, plus âgé, urbain/ périurbain et valoriser le surpoids étaient des facteurs indépendamment associés à 
la surcharge pondérale. Enfin, le haut niveau socioéconomique était aussi associé à cette surcharge. La transition nutritionnelle en cours au Sénégal dans les zones urbanisées affecte surtout les femmes matures par des facteurs culturels spécifiques contribuant au développement de ce phénomène. Des interventions locales envers celles-ci sont donc nécessaires, en tenant compte des spécificités anthropologiques du pays.

Mots clés Sénégal · Surpoids · Obésité · Image du corps · Déterminants

\section{Introduction}

Obesity has become a global public health challenge, which is now reaching pandemic proportions [1]. High income countries (HICs) were the first to experience the phenomenon of rising obesity. Low and middle income countries (LMICs) are now facing a similar but faster process of nutritional transition [2] involving rapid short-term adaptive strategies potentially causing obesity $[3,4]$. African populations are experiencing increasing levels of obesity $[5,6]$ that may exceed even those found in some HICs [7].

Growing urbanization, rural exodus and increasing internal migration in most African countries have exposed new migrants to non-communicable diseases [8]. In addition, rural migrants bring with them a sociocultural preference for stoutness (excess weight/obesity), which is not always suited to the urban ecosystem [9]. Accordingly, body fat is increasingly valued socially $[10,11]$ and becoming a risk factor of excess weight/obesity in Africa $[12,13]$. The fact that a large body size involving a high-calorie diet $[14,15]$ and low physical activity is socially valued $[16,17]$ could therefore be considered as a biocultural determinant of excess weight/obesity [18], especially in African populations $[19,20]$.

The social value of large body size had been identified several decades ago in African traditional societies [21], and still persists today despite the influence of modern lifestyles. Several studies conducted recently in Cameroon, Nigeria and Ghana $[12,22,23]$ have brought evidence of the social value attached to excess weight, especially among middle-aged and elderly subjects, which could raise serious public health issues in the context of urbanization and the nutritional transition across the continent. Historically, a large body size became socially valued in preindustrial societies in which weight gain could have been an advantage in a context of recurrent periodic shortages $[9,24]$. However, in the context of mass industrialization and easy access to processed high-calorie food, as in Western societies, thinness, and even emaciation in extreme cases, has become the social norm while stoutness is negatively perceived [25].

This study focuses on Senegal in West Africa, where little research has been attempted to assess the determinants of excess weight/obesity in perceptions of body size [26]. However, a nutritional transition is under way in this region $[27,28]$ with intensifying urbanization together with internal migration [29]. As a result, overweight/obesity has become prevalent in urban areas, where the lifestyle has become obesogenic with the development of transport and cheap processed high-calorie foods [30] that affordable to working class people living in poor urban neighborhoods [31-33]. Twenty-five years ago, the prevalence of excess weight and obesity was $16.3 \%$ and $6.1 \%$, respectively, among women living in Pikine [28], a peripheral working-class neighborhood of Dakar. Fifteen years later, in a similar sample, the figures had risen to $26.6 \%$ and $18.6 \%$ [34]. The overall prevalence of excess weight and obesity among women in Dakar as a whole was recently found to be $24.5 \%$ and $16.5 \%$ [35], a trend similar to that found in France [36].

While the industrialization of the greater Dakar area could expose its populations to obesity, this could be compounded by obesogenic body weight norms, since a large body size is valued by women living in the peripheral neighborhoods of Dakar [34,37], who therefore deliberately seek to gain weight. In the traditional view of body size in Senegal, particularly in the Wolof region, stoutness in women symbolizes a peaceful and wealthy household [38]; this has persisted with the current rural exodus [39], with the result that processed, high-calorie foods are highly valued among low socio-economic status (SES) populations in Dakar $[14,15]$. An anthropological investigation of the development of obesity in Senegal could identify how a sociocultural factor - body image - might be exposing the population to obesity and related diseases. This study therefore investigated the impact of valuing large body size on the nutritional status of Senegalese adults in the context of the nutritional transition from a rural to an urban/suburban context in Dakar.

To do so, we compared two specific and contrasting geographical areas: the Dakar urban area (city center and suburbs) and a rural area in the Wolof region (three villages in the Kaolack region: Diamaguene, Keur Ndary Ndiaye and Gandiaye), where the socio-economic conditions of the inhabitants are among the poorest in the country [40]. Using this framework, we conducted (i) a qualitative study to identify body weight norms and (ii) a quantitative study to assess the value attached to stoutness, in relation with (iii) anthropometric measurements. Overall, the results from these integrated analyses facilitated comparisons between the cultural reality of Senegalese adults and their nutritional health status. 


\section{Materials and Methods}

\section{Qualitative study}

\section{Study design}

This analysis aimed to define the sociocultural determinants of excess weight/obesity by (i) describing the different vernacular conceptions associated with body weight: fertility, power, well-being, good health and beauty [11] and (ii) detecting a potential acculturation process driven by the influence of modern lifestyles on these body weight norms. This phase was also instrumental to the completion of the quantitative study, since the variables tested by our measurement tools (Body Size Scale [BSS] and questionnaire) cannot be isolated from their sociocultural context.

\section{Sampling and process}

To determine these local norms and identify how they are influenced by the modern lifestyle, a qualitative study using focus groups explored local representations of excess weight/obesity determinants in depth [41]. Fourteen focus group discussions were held, with six participants per group recruited from different neighborhoods in the two study areas according to three criteria: age $(<25$ years, $>$ 45 years); sex and educational level ( $<$ high school level: low education, $\geq$ high school level: high education) or, if necessary, occupational category (low occupational level, e.g. manual trades, small traders; high occupational level, e.g. senior executive level, healthcare professional). The sample presented a balanced sex ratio and all the participants were Wolof speakers. The focus group discussions were held within the neighborhoods so that participants could express themselves in a familiar context without outside pressure, and recorded with a handheld recorder. The focus group discussions (and all other methods) were conducted in Wolof, the participants' vernacular language, then transcribed and translated into French.

\section{Quantitative survey}

\section{Perceptions of corpulence}

To accurately assess body perceptions and identify the social value potentially attributed to excess weight/obesity, we used a BSS. This validated tool presents photographs of real human body sizes for both sexes, covering the entire gradient of the body mass index (BMI) [42]. We then built up a body image assessment guide (BIAG) to compare local Senegalese norms with scientific body weight norms measured by the BSS, as in one of our previous studies [43]. The BIAG consists of three questions about current body size
(CBS), desired body size (DBS) and ideal body size (IBS) for oneself and for one's partner (for polygamous households, we included the first wife only). We compared the responses of participants living in urban, suburban and rural areas to assess possible changes in corpulence norms with the urbanization process. In addition, an index of social value attached to excess weight/obesity was constructed from the BSS to accurately assess the desire to gain weight.

\section{Perceptions of nutritional health status}

Using the BSS, a body self-satisfaction index was calculated to identify subjects as satisfied with their body weight, wanting to gain weight or wanting to lose weight. This BSS index was compared with BMI categories to assess the accuracy of perceived body weight.

\section{Anthropometry}

A series of anthropometric measurements was taken by trained fieldworkers, using standardized procedures [44]. Height was measured to the nearest millimeter using a portable stadiometer (Siber Hegner, Zurich, Switzerland). Weight was measured, in very light clothing, to the nearest $100 \mathrm{~g}$, using a digital beam scale (Tanita, Tokyo, Japan). This anthropometric protocol allowed us to assess the nutritional status of each respondent.

Samples. We assembled one sample in the Dakar urban area (city center and suburbs) of 393 adults $(200 \mathrm{men} /$ 193 women; 187 urban and 206 suburban subjects) and one sample of 204 adults in the Kaolack region $(84 \mathrm{men} /$ 120 women). For both areas, we used a quota sampling strategy, according to three criteria (age, sex and neighborhood) from the 2002 National Senegalese Census. In the Dakar urban area, participants were selected from all parts of the city and its peripheral region (e.g. Sacré Coeur, Cambérène). Rural subjects were strictly inhabitants of the three villages indicated above. Pregnant women were not included in the sample in order to collect reliable biological and cultural data.

\section{Data analysis}

\section{Main analyses}

For the qualitative study, analyses were performed from thematic groupings to identify relevant themes that emerged for each potential determinant of obesity [45]. After identifying the main themes, we summarized the main information from each theme and compared the social representations and practices related to these in our three subsamples.

For the quantitative study, we used the ANOVA, ANCOVA, $t$-test, chi ${ }^{2}$ and Fisher exact tests to assess 
anthropometric characteristics, body size standards and prevalence of excess weight/obesity. The average comparisons between CBS and DBS/IBS were done with paired $t$-tests.

\section{Socio-economic status}

A proxy index of household wealth was constructed using principal component analysis (PCA) of a set of variables: e.g. owner/tenant, type of house, car/truck, mobile phone, electricity. In the total sample, the first principal component explained $40.1 \%$ of the variance with an eigenvalue of 19.7 (5.3\% for the second principal component). Households were classified into three distinct groups: "low," "middle" and "high" SES according to terciles of the variable calculated from the first principal component.

Body image. The BSS was treated as a metric value, with each photograph of humans scoring 1-9 according to increasing BMI categories. The index of social value attached to excess weight/obesity was constructed as follows: 4 - DBS; since the fifth silhouette on the scale corresponds to excess weight/obesity. The body self-satisfaction index was then calculated by subtracting the CBS and DBS (CBS-DBS) [46].

\section{Relationships between beliefs, practices and body weight}

The relationships (adjusted odds ratios, 95\% confidence intervals) between excess weight/obesity and their possible determinants (sex, age, area of residence, proxy index of household wealth, educational level, index of social value attributed to excess weight/obesity) were assessed with a binary logistic regression model.

For the qualitative analyses, we used NVivo 7 software (QSR International, Melbourne, Australia) to synthesize the main focus group outcomes. For the quantitative analyses we used Statistica 7 software (Statsoft Inc, Tulsa, OK, USA) to produce descriptive statistics and PCA(s), and MyStat 12 software (Systat Software Inc, San Jose, CA, USA) for the logistic regression. Finally, equal weight was assigned to the qualitative and quantitative approaches in the interpretation of our findings.

\section{Results}

\section{Qualitative study}

\section{Traditional value of large body size}

Stoutness is traditionally perceived as a sign of wealth and prosperity in the household. Excess weight is associated with strength, good physical and mental health and vitality.
Stoutness represents fertility in women and their ability to maintain a peaceful atmosphere in their household, and in men their ability to support their family.

"In principle, ngande [being fat], this is not a disease in our culture. The opposite, tuuti [being small], is a disease here because am yaram [being fat] is really important, especially for women. A big body shows that you have a good life. People consider that if you are not am yaram, it is because you are not well in your life. You have problems, you do not have peace of mind [xel mu dal]. For you and your family, nothing works. For us, body weight reflects economic status." [Older urban woman, high SES]

"The man, he has to be a boss. But being a boss at work, in the neighbourhood or at home is not the same. At work, he must command, he must exert his power; at home, he demonstrates his power. This is the birru patron [chicken belly]. This is the belly that shows you eat a lot of chicken." [Younger rural man, low level of education]

\section{Urbanization and the value of large body size}

The development of urban areas in Senegal implies an ideal conception of the modern lifestyle, where success is seen as possible for rural and migrant populations who idealize Western culture. Integrating into an urban lifestyle is associated with weight gain, which is rare in the village context, as a symbol of integration into the city, of doing well from its abundance. But in rural areas, only moderate corpulence is valued, since being very fat is not suited to rural labor. Therefore, the social value of stoutness has increased with the emergence of the modern lifestyle, seen as a symbol of wealth and prosperity, especially in middle-aged and older married women with a lower SES.

"Nowadays, women want to gain weight. Before, it was not like this. Now, a woman who is not fat tries to put on weight, for instance by using medication (corticosteroids). This is very dangerous. You put on weight very quickly; but later your face and the rest of your body become deformed. And these women want to be beautiful... [dieekk: a stout married woman who is content in her household]." [Older rural woman, high SES]

"Women today, especially married women; most of them do not want to be tuuti [thin]. Sometimes, you see a tuuti [slim] woman, and people say that she is HIV positive or has many problems in her life. People say a lot of nonsense about her. This is why tuuti women take medications to put on weight." [Younger rural woman, high educational level] 


\section{Competition in the household}

With migration to the city and excess weight becoming overvalued, middle-aged and older married women compete to demonstrate their well-being and the success of their husband and household to others. This competitive atmosphere can be found outside the home, but particularly between cowives in the household.

"If you are a co-wife and you are wow [thin], your cowife will tend to give you the evil eye. If you have an argument with her, she will always have something bad to say to you, by criticising your thinness. To her, you are skinny. This will hurt you. That's why to find a way out, you will be looking for medication to become ngande [fat] yourself." [Younger rural woman, high educational level]

"Even though we know the serious consequences of taking medication to put on weight, a jealous co-wife will want to put on weight to rival another co-wife and stop her from criticising her as not a real woman." [Younger rural man, low educational level]

\section{How female stoutness is valued}

Gaining weight during marriage is important and particularly expected in women, since an overweight woman is a symbol of her husband's wealth through economic success. Therefore, there is more social pressure on women to become fat, as their weight is the symbol of household prosperity.

"We don't like wow [thin] people, especially women. It is better to be wow [thin] for a man than a woman. If you say to a women that she is wow [thin], she will be angry with you all the rest of her life. She wants to be am yaram [fat]." [Older urban man, low SES]

"The woman should gain weight. When a woman is wow [thin], people say that her husband will soon be looking for a co-wife." [Younger urban woman, low educational level]

\section{Acculturation of young people}

Nevertheless, with the influence of western media and medical discourse, young people are beginning question the social value of a large body size. Some educated urban women devalue stoutness to the point of becoming "obesophobic":

"Most series, like Telenovelas, are set on beaches where young women have beautiful bodies. Now with the summer arriving, young Senegalese women also want to have a beautiful body. They all start dieting so they can wear their two-piece bathing suits on the beach." [Younger urban woman, high educational level]

"Now there's the sports ground phenomenon. The young men go to the beach to train. They go just to build up their muscles. They don't have money so they work on their appearance." [Younger urban man, low educational level]

\section{Quantitative survey}

\section{Sociodemographic characteristics}

The sex ratio for the urban and suburban samples was approximately even, while women were moderately overrepresented in the three rural samples, with about one quarter of the subjects over 45 years of age. Most urban and suburban subjects had at least attended primary school and had electricity at home, whereas almost half of the rural subjects had never been to school and the majority did not have electricity. Finally, we observed an over-representation of both second- and third-generation migrants in the urban and suburban samples (Table 1).

\section{Perceptions of corpulence}

Concerning men's perceptions (Fig. 1), all groups considered themselves to be in the normal weight category. The desire to become overweight was significant only in the urban and rural groups (CBS vs DBS: $p<0.01$ and $p<$ 0.001 ), and slight in the suburban group. Overall, the participants in the three groups selected DBS and IBS in the normal weight category. The suburban group had the lowest DBS and IBS averages and the highest CBS average. There was no significant difference between CBS and IBS in this group, unlike the two others, which had a higher IBS than CBS (urban: $p<0.001$, rural: $p<0.001$ ) (Fig. 1).

Concerning women's perceptions (Fig. 2), the urban and suburban groups saw themselves on the lower threshold of excess weight whereas rural women considered themselves to be in the normal weight category $(p<0.001)$ and wanted to gain weight $(p<0.001)$. The IBS averages were on the lower threshold of excess weight, except for rural women who clearly preferred the overweight category $(p<0.001)$ with an IBS significantly higher than DBS $(p<0.05)$ and CBS $(p<0.001)$ (Fig. 2).

\section{Anthropometry}

Excess weight and obesity in the total sample were more prevalent in the urban and suburban areas (Table 2). 


\begin{tabular}{|c|c|c|c|c|c|c|}
\hline & \multicolumn{2}{|c|}{ Urban area } & \multicolumn{2}{|c|}{ Suburban area } & \multicolumn{2}{|c|}{ Rural area } \\
\hline & $N$ & $\%$ & $N$ & $\%$ & $N$ & $\%$ \\
\hline Men & 96 & 51.3 & 104 & 50.5 & 84 & 41.2 \\
\hline Women & 91 & 48.7 & 102 & 49.5 & 120 & 58.8 \\
\hline \multicolumn{7}{|l|}{ Age } \\
\hline & $N$ & $\%$ & $N$ & $\%$ & $N$ & $\%$ \\
\hline$[18-25]$ & 49 & 26.2 & 60 & 29.1 & 65 & 31.9 \\
\hline$[26-45]$ & 92 & 49.2 & 95 & 46.1 & 84 & 41.2 \\
\hline$\geq 46$ & 46 & 24.6 & 51 & 24.8 & 55 & 27.0 \\
\hline \multicolumn{7}{|l|}{ Education } \\
\hline & $N$ & $\%$ & $N$ & $\%$ & $N$ & $\%$ \\
\hline University & 24 & 12.8 & 18 & 8.7 & 4 & 2.0 \\
\hline High school & 18 & 9.6 & 20 & 9.7 & 13 & 6.4 \\
\hline Secondary school & 44 & 23.5 & 43 & 20.9 & 40 & 19.6 \\
\hline Primary school & 61 & 32.6 & 68 & 33.0 & 46 & 22.5 \\
\hline Koranic school & 1 & 0.5 & 1 & 0.49 & 0 & 0.0 \\
\hline None & 39 & 20.9 & 56 & 27.2 & 101 & 49.5 \\
\hline \multicolumn{7}{|c|}{ Socio-economic status } \\
\hline & $N$ & $\%$ & $N$ & $\%$ & $N$ & $\%$ \\
\hline Family house & 185 & 98.9 & 200 & 97.1 & 3 & 1.5 \\
\hline No data & 2 & 1.1 & 4 & 1.9 & 9 & 4.4 \\
\hline Tap water & 172 & 92.0 & 199 & 96.6 & 3 & 1.5 \\
\hline No data & 6 & 3.2 & 6 & 2.9 & 11 & 5.4 \\
\hline Electricity & 179 & 95.7 & 200 & 97.1 & 3 & 1.5 \\
\hline No data & 1 & 0.5 & 0 & 0.0 & 13 & 6.4 \\
\hline \multicolumn{7}{|l|}{ Migration status } \\
\hline & $N$ & $\%$ & $\vec{N}$ & $\%$ & & \\
\hline 1st generation & 35 & 18.7 & 49 & 23.8 & N/A & $\mathrm{N} / \mathrm{A}$ \\
\hline 2nd generation & 82 & 43.9 & 99 & 48.1 & N/A & $\mathrm{N} / \mathrm{A}$ \\
\hline 3rd generation & 68 & 36.4 & 57 & 27.7 & N/A & $\mathrm{N} / \mathrm{A}$ \\
\hline No data & 2 & 1.07 & 1 & 0.5 & & \\
\hline
\end{tabular}

\section{Perceptions of nutritional health status}

The majority of overweight subjects were not able to identify their nutritional status. Almost half of the overweight subjects $(48.7 \%)$ and more than half of the obese subjects $(57.5 \%)$ were satisfied with their body weight (Table 3 ). Using the index of social value attached to excess weight/ obesity, we observed that the majority of subjects who valued excess weight/obesity were women (urban men/women: 41.8 vs $58.0 \%, p<0.05$; suburban men/women: 35.7 vs $55.7 \%, p<0.01$; rural men/women: 52.6 vs $62.7 \%$, NS). In women only, we observed that the DBS was significantly higher in the $>25$-year-old age group (women: $5.2 \pm 1.8 \mathrm{vs}$ $4.5 \pm 1.7, p<0.01$; men: $4.3 \pm 1.6$ vs $4.3 \pm 1.7$ ) (Table 3 ).

\section{Analysis of excess weight/obesity determinants}

The comparison of overweight/obese ( $\geq 25 \mathrm{~kg} / \mathrm{m}^{2}$ ) with nonoverweight subjects, using binary logistic regression analysis (Table 4), showed independent effects of gender, age, living area and the value given to excess weight/obesity. Finally, univariate analyses showed that a high SES was more likely to be associated with being overweight/obese $(p<0.05)$ (Table 4).

\section{Discussion}

This study investigated a specific biocultural determinant of obesity - the value attached to large body size - in the context 


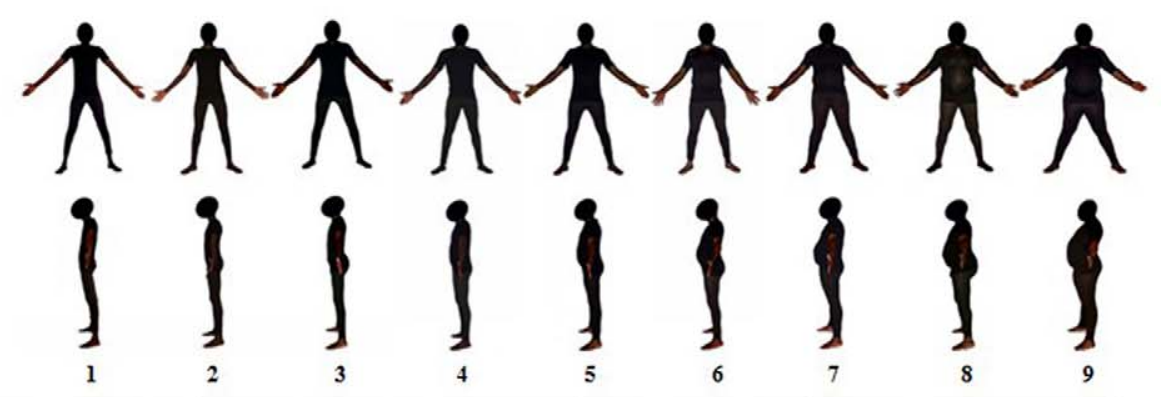

\begin{tabular}{|c|c|c|c|c|c|c|c|}
\hline $\begin{array}{l}\text { Scientific } \\
\text { norms } \\
\text { (Etic) }\end{array}$ & $P$ & Underweight & Normal weight & Overweight & 1 & $\begin{array}{c}\text { Obesity } \\
2\end{array}$ & 3 \\
\hline 更 & $\begin{array}{l}\text { CBS ठ } \\
\text { NS } \\
3.8 \pm 1.5 \\
4.0 \pm 1.6 \\
3.6 \pm 1.7 \\
\\
\text { DBS } 6 \\
\text { NS } \\
\\
4.2 \pm 1.6 \\
4.1 \pm 1.4 \\
4.5 \pm 1.8 \\
\\
\text { IBS } \delta \\
\text { NS } \\
\\
4.7 \pm 1.5 \\
4.2 \pm 1.4 \\
4.6 \pm 1.7\end{array}$ & & 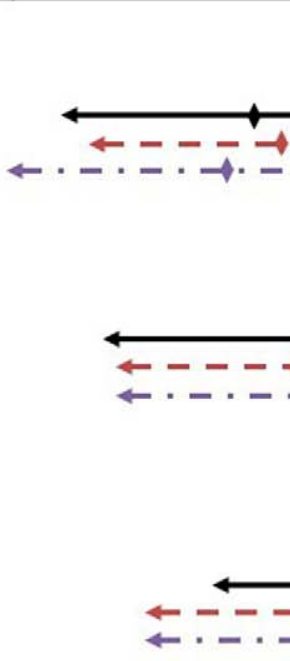 & 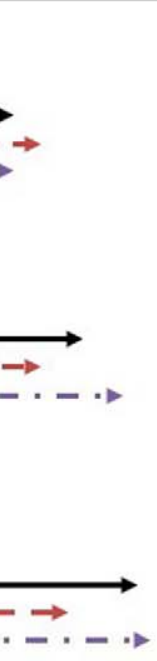 & & & \\
\hline
\end{tabular}

Urban area

Suburb area - - Rural area - - .

Fig. 1 Perceptions of body size for male BSS. CBS: Current body size, DBS: Desired body size, IBS: Ideal body size. NS: Not significant / Perceptions du volume corporel sur la planche masculine BSS. CBS : Current Body Size (volume corporel actuel), DBS : Desired body size (volume corporel désiré), IBS : Ideal body size (volume corporel idéal). NS : not significant (Non significatif)

of the nutritional transition in Senegal. Overall, we observed that our study population experienced health consequences from this change in lifestyle where there was a higher degree of urbanization. More precisely, this was associated with a dynamic socio-ecological obesogenic context, through internal migration from a rural area (Kaolack region) to an urban area (Dakar). Senegalese people who have settled in suburban and urban areas have higher rates of excess weight and obesity, with several determinants acting in different ways influencing the spread of excess weight/obesity, as has been observed in other migrant populations in urban areas of LMICs and HICs [47]. The nutritional transition seems to be under way among urban/suburban Senegalese women with a mean BMI of $\sim 25 \mathrm{~kg} / \mathrm{m}^{2}$, a tendency already recently observed in Dakar [35]. This suggests that women are more sensitive to the obesogenic effects of the nutritional transition that accompanies an urban lifestyle [48], as in most LMICs [49], and that this is exacerbated by the value they attach to excess weight/obesity.
Nevertheless, despite the social value attached to excess weight/obesity in traditional Senegalese culture, accentuated by the current portrayal of Dakar as an Eldorado (based on our qualitative study), the value attached to excess weight/ obesity seems to be decreasing overall in Dakar (urban/suburban areas), particularly among young women, even though women initially desired a higher average body size than men. Senegalese people seem to be adapting their body size norms to the obesogenic urban environment and to modern perceptions of body size, like other African populations [50,51], since the younger generations, unlike older people, are no longer valuing excess weight/obesity [52]. This is happening to such an extent among young Senegalese people exposed to Western media and medical discourse that some are beginning to develop the first symptoms of anorexia nervosa and body dysmorphic disorder, according to the literature on African urban youth $[38,53,54]$. Thus, the desire to lose weight observed in many subjects of normal weight might be linked to the 


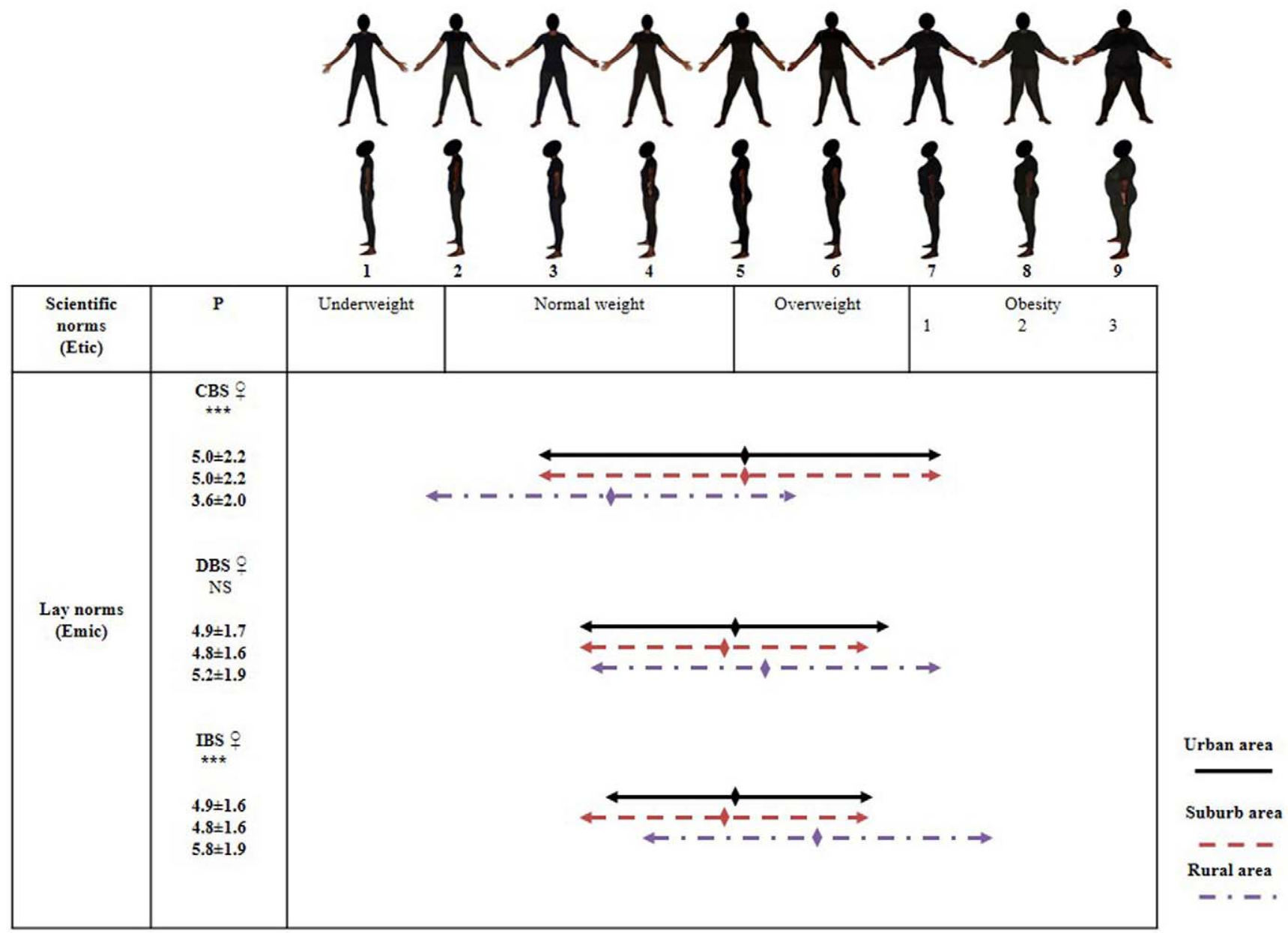

Fig. 2 Perceptions of body size for female BSS. CBS: Current body size, DBS: Desired body size, IBS: Ideal body size. NS: Not significant. ***: $\mathrm{p}<0.001 /$ Perceptions du volume corporel sur la planche féminine BSS. CBS : Current Body Size (volume corporel actuel), $D B S$ : Desired body size (volume corporel désiré), IBS : Ideal body size (volume corporel idéal). NS : Not significant (non significatif). $* * *: p<0,001$

\begin{tabular}{|llll|}
\hline $\begin{array}{l}\text { Table } 2 \\
\text { 2 Prevalence of overweight and obesity / Prévalence }\end{array}$ \\
\hline \% & No excess weight & Excess weight & $\boldsymbol{p}$ \\
\hline Urban & $70.4(131)$ & $29.6(55)$ & \\
Suburban & $70.4(143)$ & $29.6(60)$ & \\
Rural & $91.5(184)$ & $8.5(17)$ & $* * *$ \\
\hline \multicolumn{5}{|c|}{ No obesity } & Obese & $\boldsymbol{p}$ \\
\hline Urban & $88.2(164)$ & $11.8(22)$ & \\
Suburban & $88.2(179)$ & $11.8(24)$ & $* * *$ \\
Rural & $98.0(197)$ & $2.0(4)$ & \\
\hline$* * *: p<0.001$ & & & \\
\hline
\end{tabular}

emerging modern cult of thinness. Nevertheless, in the Dakar urban area, both desired and ideal body sizes were still close to excess weight, as observed in other African urban areas [12], while the prevalence of excess weight was higher than in the rural areas, as also in several other African countries [6]. The social value attached to excess weight/obesity is an independent risk factor of excess weight/obesity [23] and, not surprisingly, the majority of overweight/obese subjects do not want to lose weight [34]. Middle-aged and older women seem to represent the main group displaying this high-risk behavior, as also observed in Nigeria [22].

Various practices are used in Senegal to put on weight. As observed by Rguibi and Belahsen [16] among Sahraoui women in Morocco, corticosteroids are commonly taken by married women to prove by their corpulence that their household is peaceful. Another strategy to gain weight is to decrease physical activity by promoting and adopting idleness, especially among women of low SES living in the peripheral area of Dakar. Indeed, to these urban workingclass women, staying peacefully at home, being fat and surrounded by cleaning women is the way to success, as also 
Table 3 Self-assessment of health status / Auto-appréciation de l'état de santé

\begin{tabular}{|llll|}
\hline BMI & Want to lose weight & Satisfied & Want to gain weight \\
\hline Underweight & $27.8(30)$ & $8.3(9)$ & $63.9(69)$ \\
Normal weight & $52.6(170)$ & $15.2(49)$ & $32.2(104)$ \\
Overweight & $43.4(33)$ & $48.7(37)$ & $7.9(6)$ \\
Obese & $36.2(17)$ & $57.5(27)$ & $6.4(3)$ \\
\hline$* * *: p<0.001$ & & & \\
\hline
\end{tabular}

Table 4 Odds ratio and 95\% confidence limits for overweight/obese subjects, adjusted by binomial logistic regression analysis, and compared to subjects who are not overweight / Odds ratio et intervalles de confiance à $95 \%$ pour les sujets en surpoids et obèses, ajustés par une régression logistique et comparés avec les sujets qui ne le sont pas

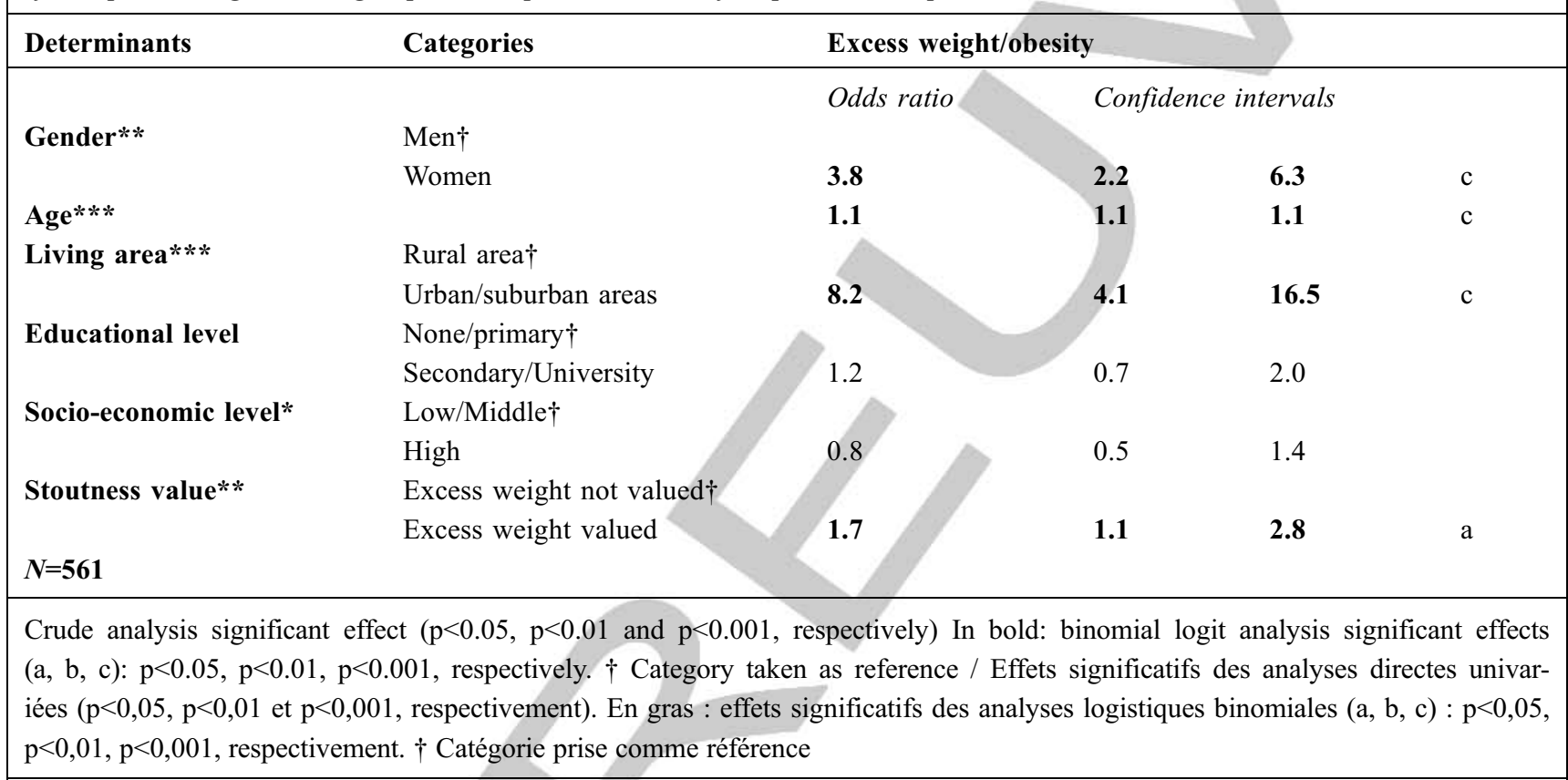

observed by Rguibi and Belahsen [16] in Morocco and by Cohen et al. in Cameroon [23].

Some specific traditional dietary practices also exist to gain weight, especially among Senegalese women, such as consuming high-calorie meals like ruy [millet porridge without grains] and foõdé [millet porridge with grains]. However, this is more common among Senegalese women living in suburban areas, as a way of showing off the economic success of their household, than among rural women who still have to take on manual activities that demand physical fitness $[55,56]$. It seems obvious that dietary practices are changing with urbanization, since the population is more exposed to processed high-calorie food. Consuming modern high-calorie food and adding processed oil to all recipes in the Dakar urban area could be another strategy to gain weight. However, another study focusing on this determinant would be needed to identify this factor, especially in the light of the value attached to stoutness, which is identified as a determinant of excess weight/obesity in middleaged married women.

The Senegalese living in Dakar are thus exposed to both physical and social obesogenic environments. As observed in other populations [3], the duration of urban residence is a risk factor for obesity to which subjects who tend to value excess weight/obesity, especially women, are more exposed. This study therefore suggests that public health policies for obesity prevention need to be adapted to the specific characteristics of migrant populations $[57,58]$ to ensure that evolving biocultural determinants in different socio-ecological areas in Senegal $[59,60]$ are taken into account. To achieve this goal in the future, we propose a set of general recommendations [61] in two areas: public health practice and research targeted to public health personnel in academia, community-based contexts and government agencies. The findings from this 
study could clarify the exposure levels of urban Senegalese to excess weight and obesity according to their anthropological specificities, and thus help to promote health initiatives among Senegalese migrants or immigrants to the Dakar urban area, in order to connect individuals with healthcare services in urban Senegal [62].

\section{Conclusion}

This study demonstrates that the social value attached to large body size is a driver of excess weight and obesity in rural to urban migrants in Senegal. Comparative studies of migrants in other African countries would be needed to provide more evidence on whether this is a general trend. To identify the exposure levels of migrants to obesity, local and global health policies need to take the anthropological specificities of migration pathways into account, such as perceptions of food and body weight in particular.

Acknowledgments : Emmanuel Cohen is supported by the South African DST/NRF Centre of Excellence in Human Development. Particular thanks to Luisa Michelotti and other investigators in the field.

Conflict of Interest: No conflict of interest and no competing financial interests.

\section{References}

1. Popkin BM, Adair LS, Ng SW (2012) Global nutrition transition and the pandemic of obesity in developing countries. Nutr Rev 70:3-21

2. Morris K (2010) UN raises priority of non-communicable diseases. Lancet 375:1859

3. Olszowy KM, Pomer A, Dancause KN, et al (2015) Impact of modernization on adult body composition on five islands of varying economic development in Vanuatu. Am J Hum Biol 27:832-44

4. Downey G (2016) Being human in cities: Phenotypic bias from urban niche construction. Curr Anthropol 57:52-64

5. Stevens GA, Singh GM, Lu Y, et al (2012) National, regional, and global trends in adult overweight and obesity prevalences. Popul Health Metr 10:22

6. Steyn NP, Mchiza ZJ (2014) Obesity and the nutrition transition in Sub-Saharan Africa. Ann N Y Acad Sci 1311:88-101

7. Connor Gorber S, Tremblay M, Moher D, Gorber B (2007) A comparison of direct vs. self-report measures for assessing height, weight and body mass index: A systematic review. Obes Rev $8: 307-26$

8. Oyebode O, Pape UJ, Laverty AA, et al (2015) Urban and migrant differences in non-communicable disease risk-factors in middle income countries: A cross-sectional study of WHO-SAGE Data. PLoS One 10:0122747

9. De Garine I (1990) Adaptation biologique et bien-être psychoculturel. BMSAP 2:151-73

10. Blocker DE, Freudenberg N (2001) Developing comprehensive approaches to prevention and control of obesity among low-income, urban, African-American women. J Am Med Womens Assoc 56:59-64

11. Mvo Z, Dick J, Steyn K (1999) Perceptions of overweight African women about acceptable body size of women and children. Curationis 22:27-31

12. Appiah CA, Otoo GE, Steiner-Asiedu M (2016) Preferred body size in urban Ghanaian women: Implication on the overweight/ obesity problem. Pan Afr Med J [in press]

13. Cohen E, Boetsch G, Palstra FP, Pasquet P (2013) Social valorisation of stoutness as a determinant of obesity in the context of nutritional transition in Cameroon: The Bamileke case. Soc Sci Med 96:24-32

14. Bricas N (2008) La pluralité des références identitaires des styles alimentaires urbains en Afrique. Les nouvelles figures des marchés agroalimentaires. Apports Croisés L'économie Sociol Gest 149-59

15. Ndoye F, Diop A (2001) Evolution des styles alimentaires à Dakar. ENDA-GRAF/CIRAD, Dakar, $62 \mathrm{p}$

16. Rguibi M, Belahsen R (2006) Fattening practices among Moroccan Saharawi women. East Mediterr Health J 12:619-24

17. Warnier JP (2009) Régner au Cameroun : le roi-pot, Karthala Editions, Paris, $338 \mathrm{p}$

18. Brewis AA (2011) Obesity: cultural and biocultural perspectives. Rutgers University Press, New Brunswick, New Jersey, $232 \mathrm{p}$

19. Flynn K, Fitzgibbon BM (1998) Body images and obesity risk among black females: a review of literature. Ann Behav Med 20:13-24

20. Krauss RC, Powell LM, Wada R (2012) Weight misperceptions and racial and ethnic disparities in adolescent female body mass index. J Obes 205393

21. De Garine I, Pollock NJ (1995) Social aspects of obesity. Gordon and Breach Publishers, Amsterdam, $352 \mathrm{p}$

22. Okoro EO, Oyejola BA, Etebu EN, et al (2014) Body size preference among Yoruba in three Nigerian communities. Eating and Weight Disorders-Studies on Anorexia. Bulim Obes 19:77-88

23. Cohen E, Amougou N, Ponty A, et al (2017) Nutrition transition and biocultural determinants of obesity among Cameroonian migrants in urban Cameroon and France. Int J Environ Res Public Health [in press]

24. Brown PJ, Konner M (1987) An anthropological perspective on obesity. Ann N Acad Sci 499:29-46

25. Boetsch G (2006) Les variations historiques et culturelles de la morphologie corporelle. Médecine et nutrition 42:29-35

26. Macia E, Cohen E, Gueye L, et al (2017) Prevalence of obesity and body size perceptions in urban and rural Senegal: new insight on the epidemiological transition in West Africa. Cardiovasc J Afr [in press]

27. Abubakari AR, Lauder W, Agyemang C, et al (2008) Prevalence and time trends in obesity among adult West African populations: A meta-analysis. Obes Rev 9:297-311

28. Maire B, Delpeuch F, Cornu A, et al (1992) Urbanisation et transition nutritionnelle en Afrique sub-saharienne: les exemples du Congo et du Sénégal. Rev D'épidémiologie Santé Publique 40:252-8

29. Duboz P, Macia E, Chapuis Lucciani N, et al (2012) Migration and hypertension in Dakar, Senegal. Am J Phys Anthropol 149:250-8

30. Macia E, Duboz P, Gueye L (2010) Prevalence of obesity in Dakar. Obes Rev 11:691-4

31. Sobal J, Stunkard AJ (1989) Socio-economic status and obesity: A review of the literature. Psychol Bull 105:260-75

32. Drewnowski A (2009) Obesity, diets, and social inequalities. Nutr Rev 67:36-9

33. Temple NJ, Steyn NP (2011) The cost of a healthy diet: A South African perspective. Nutrition 27:505-8 
34. Holdsworth M, Gartner A, Landais E, et al (2004) Perceptions of healthy and desirable body size in urban Senegalese women. Int J Obes 28:1561-8

35. Macia E, Gueye L, Duboz P (2016) Hypertension and obesity in Dakar, Senegal. PloS One 11:0161544

36. Eschwege E, Charles MA, Basdevant A (2012) ObEpi: Enquête Epidémiologique Nationale sur le Surpoids et L'obésité, Roche, Basel, $60 \mathrm{p}$

37. Gning SB, Thiam M, Fall F, et al (2007) Le diabète sucré en Afrique subsaharienne. Aspects épidémiologiques, difficultés de prise en charge. Médecine Trop 67:607-11

38. Ndiaye L (2006) Les représentations sociales du corps de la femme en pays wolof sénégalais : «tradition et modernité ». In: Ly B (ed) Sociétés en devenir. Presses Universitaire de Dakar, Dakar, pp 213-34

39. Duboz P, Macia E, Gueye L, et al (2011) Migrations internes au Sénégal. Caractéristiques socioéconomiques, démographiques et migratoires des Dakarois. Divers Urbaine 11:113-35

40. AG/GRN-GTZ (2004) Convention locale de la gestion des ressources naturelles du terroir communautaire de Taïba Niassène, République du Sénégal, $21 \mathrm{p}$

41. Stewart D, Shamdasani P (1990) Focus group: Theory and practice. Sage Publications, Newburg Park, $153 \mathrm{p}$

42. Cohen E, Bernard JY, Ponty A, et al (2015) Development and validation of the body size scale for assessing body weight perception in African populations. Rev PLoS One 10:0138983

43. Cohen E, Pasquet P (2011) Development of a new body image assessment scale in urban Cameroon: An anthropological approach. Ethn Dis 21:288

44. Weiner JS, Lourie JA (1981) Practical human biology. Academic Press, New York, $439 \mathrm{p}$

45. Mason J (2002) Qualitative researching. Sage, London, $232 \mathrm{p}$

46. Williamson DA, Gleaves DH, Watkins PC, Schlundt DG (1993) Validation of self-ideal body size discrepancy as a measure of body dissatisfaction. J Psychopathol Behav Assess 15:57-68

47. Siervo M, Grey P, Nyan OA, Prentice AM (2006) A pilot study on body image, attractiveness and body size in Gambians living in an urban community. Eat Weight Disord-Stud Anorex Bulim Obes 11:100-9

48. Fezeu LK, Assah FK, Balkau B, et al (2008) Ten-year changes in central obesity and BMI in rural and urban Cameroon. Obesity $16: 1144-7$
49. Monteiro CA, Conde WL, Lu B, Popkin BM (2004) Obesity and inequities in health in the developing world. Int $\mathrm{J}$ Obes Relat Metab Disord 9:1181-6

50. Renzaho AM, McCabe M, Swinburn B (2012) Intergenerational differences in food, physical activity, and body size perceptions among African migrants. Rev Qual Health Res 22:740-54

51. Szabo CP, Allwood CW (2006) Body figure preference in South African adolescent females: A cross cultural study. Afr Health Sci 6:201-6

52. Dapi LN, Omoloko C, Janlert U, et al (2007) "I eat to be happy, to be strong, and to live." Perceptions of rural and urban adolescents in Cameroon, Africa. J Nutr Educ Behav 39:320-6

53. Hitzeroth V, Wessels C, Zungu Dirwayi N, et al (2001) Muscle dysmorphia: a South African sample. Psychiatry Clin Neurosci 55:521-3

54. Sow AM (2002) Médecine interne et image de soi: canons de beauté ou indicateurs de santé ? Médecine Trop 62:577-81

55. De Garine I (1962) Usages alimentaires dans la région de Khombole (Sénégal). Cahiers d'études africaines 218-65

56. Sear R, Marlowe FW (2009) How universal are human mate choices? Size does not matter when Hadza foragers are choosing a mate. Biol Lett 5:606-9

57. Delavari M, Farrelly A, Renzaho A, et al (2013) Experiences of migration and the determinants of obesity among recent Iranian immigrants in Victoria, Australia. Rev Ethn Health 18:66-82

58. Delavari M, Sonderlund AL, Mellor D, et al (2015) Migration, acculturation and environment: determinants of obesity among Iranian migrants in Australia. Rev Int J Env Res Public Health 12:1083-98

59. Abraido-Lanza AF, Armbrister AN, Florez KR, Aguirre AN (2006) Toward a theory-driven model of acculturation in public health research. Am J Public Health 96:1342-46

60. Himmelgreen DA, Pérez Escamilla R, Martinez D, et al (2004) The longer you stay, the bigger you get: Length of time and language use in the US are associated with obesity in Puerto Rican women. Am J Phys Anthropol 125:90-6

61. Lara M, Gamboa C, Kahramanian MI, et al (2005) Acculturation and Latino health in the United States: A review of the literature and its sociopolitical context. Annu Rev Public Health 26:367-97

62. Frisillo Vander Veen D (2015) Obesity, obesity health risks, resilience, and acculturation in black African immigrants. Int J Migr Health Soc Care 11:179-93 